\title{
Malnutrition in African Adults
}

\section{Protein Storage}

\author{
By E. G. HOLMES, E. R. JONES AND MARGARET W. STANIER \\ Department of Physiology and $R / \mathrm{x} 44$ Research Unit, \\ Makerere College, Kampala, Uganda
}

(Received 12 December 1953)

In 1948 , we had occasion to undertake a series of nitrogen-balance experiments on African patients in Mulago hospital, with a view to assessing their state of nutrition with respect to protein. Some had been admitted to hospital suffering from severe hookworm anaemia, others with enlargement of the liver and spleen sufficient to bring them into hospital. Others bore the diagnosis simply of 'malnutrition'. They all gave a history, extending over years, of a diet grossly deficient in protein, and from which animal protein was almost absent. Malnutrition of the type encountered here differs from that seen in Europe and America in that very serious protein deficiency may accompany a diet of reasonable calorie value. Bayliss's dictum 'Take care of the calories, and the protein will take care of itself' is emphatically not true in this part of Africa. This is because the common carbohydrate staples, sweet potato, cassava, and plantain contain $2 \%$ or less of protein.

Accurate figures for food consumption among the general population are lacking, but the following data are of interest. They were calculated from figures in a report of a cost-of-living survey carried out by the East African Statistical Department (r952). The number of individuals (all adult male labourers) observed was I IO, and the period of observation 30 consecutive days. The daily food consumption was: protein $53 \mathrm{~g}$, carbohydrate $525 \mathrm{~g}$, fat $42 \mathrm{~g}$. This provided $2647 \mathrm{Cal}$. Only $9 \mathrm{~g}$ of the protein were of animal origin. Neither milk, eggs, butter nor cheese were consumed.

Our subjects all gave a history of a diet consisting mainly of sweet potato, cassava, or plantain. Groundnuts or beans or both were eaten about once weekly, meat or fish not more often than once monthly, and eggs, milk, or cheese were never consumed. Although, in the absence of diet surveys, we cannot say what proportion of the population live on a diet of this kind, it is quite certain that the type of case with which we have been dealing is extremely common, and examples can be obtained from the general wards of the hospital whenever required. We were not surprised to find that these subjects retained nitrogen when placed on a diet high in animal protein and calories. But as the period of observation extended, and the nitrogen retention continued, we began to realize that some mechanism or mechanisms, not hitherto clearly recognized, must be playing an important part. We have made a long series of observations on the haematology and serum protein of these subjects. We shall, however, confine ourselves in this paper to the question of nitrogen and phosphorus balances. 
EXPERIMENTAL

\section{Control experiments}

As a general check on our technique we carried out control experiments on presumably normal persons. The subjects were two European females (M.W.S. and J.G.) on the research staff (one of these for two separate periods), a European male (R.M.) and two African students (B. and N.) R.M. was a university lecturer with considerable experience as the subject of metabolic experiments, who kindly volunteered to go on to a nitrogen balance for us. He was leading an active life at the time and is a man of exceptionally good physique. He habitually consumes a high-protein diet. The period of continuous observation was 21 days.

\section{Experimental methods}

General. The subjects studied, all adult males, were in-patients in Mulago Hospital, transferred to us through the courtesy of Dr H. C. Trowell and Dr P. W. Hutton. They bore the diagnosis of either 'hookworm anaemia', 'malnutrition' or 'hepatomegaly'. They were housed in a six-bedded ward which was under the charge of a nursing sister, a member of the staff of the Research Unit and experienced in metabolic work. She had her own African staff, and neither she nor they had other responsibilities. Raw food was sent to the ward and prepared in the ward kitchen either by the sister herself or under her close supervision; raw and cooked weights were recorded. The sister weighed the portions for each patient, and weighed back any unconsumed portions. She supervised the collection of excreta. As an additional check, for some time one or other of the laboratory research staff took duty in the ward, so that there was supervision throughout the whole of the $24 \mathrm{~h}$. There was no change in the results during this period.

Nitrogen balance was followed for many days in these subjects. Subsequently it became necessary to make observations on the effect of cortisone and ACTH, and nitrogen balances were repeated in these conditions.

Diet. The diets given were based on the foodstuffs supplied by the hospital. The staples were rice, maize meal, plantains, bread, beans, groundnuts and meat. The protein content was increased for our purposes by adding dried separated milk or meat or both. If it was desired to increase the calorie value without altering the protein, this was done by adding extra sugar or ghee (clarified butter). The calorie value of the diets we administered was high, averaging between 3000 and $4000 \mathrm{Cal} /$ /day. The protein content was not as a rule allowed to drop below 100 and was frequently raised to $180-200 \mathrm{~g}$. Most of it was contributed by dried, separated milk, or meat. The purpose of keeping up the calorie value of the diet was, of course, to favour the establishment of nitrogenous equilibrium by utilizing the protein-sparing action of other foodstuffs. Lowering the calorie value resulted in a small but definite rise in nitrogen excretion.

The protein, carbohydrate and fat contents of the diets were usually calculated from food tables (Fox \& Goldberg, 1944; Platt, I945). A series of observations, however, was carried out in which a portion (one-tenth) of all food eaten was saved, and the 
total nitrogen determined in the laboratory. The procedure was as follows. A capsule of carmine was administered to the patient. The appearance of a carmine-stained stool was taken as the beginning of the experimental period. From that time a one-tenth portion of all food eaten by each patient was set aside. Each $24 \mathrm{~h}$ portion was thoroughly mixed in a Waring blendor, a suitable amount weighed, dried at $100^{\circ}$, and the dry weight determined. The dried samples were preserved in a desiccator until analysed. The end of the experimental period was determined by a second carmine marker in the stools.

The results of these observations appear in Table $I$, and show that no error was involved in calculating from food tables.

Collection of excreta. The urine was passed into urinals, which were emptied into Winchester quart bottles containing toluene and kept in the ward refrigerator. Stools were passed into individual receptacles marked for each patient. The volume of urine, recorded in the ward, was checked again in the laboratory, where the specific

Table I. Nitrogen content of diets given to African patients and comparison of resulting nitrogen balances, determined from tables of food composition (Fox $\&^{\circ}$ Goldberg, I944; Platt, 1945) and by direct analysis

\begin{tabular}{|c|c|c|c|c|c|}
\hline bject & $\begin{array}{c}\text { Duration of } \\
\text { experiment } \\
\text { (days) }\end{array}$ & $\begin{array}{l}\text { Nitrogen in } \\
\text { diet by } \\
\text { analysis }(a) \\
\text { (g) }\end{array}$ & $\begin{array}{l}\text { Nitrogen in } \\
\text { diet by } \\
\text { calculation (b) } \\
\text { (g) }\end{array}$ & $\begin{array}{l}\text { Nitrogen balance } \\
\text { from }(a) \\
(\mathrm{g})\end{array}$ & $\begin{array}{l}\text { Nitrogen balance } \\
\text { from }(b) \\
(\mathrm{g})\end{array}$ \\
\hline & 15 & x67 & 162 & $+55^{\circ} 3$ & $+5^{\circ} \cdot 1$ \\
\hline & 6 & 129 & 13 & +50.5 & +54.9 \\
\hline ikali & To & 164 & 166 & $+48 \cdot 3$ & +50.4 \\
\hline
\end{tabular}

gravity was measured. The stools were weighed in the laboratory, well mixed, a portion was weighed out, dried at $100^{\circ}$, powdered and mixed, and kept in a glassstoppered bottle until analysed. In certain cases, to save time and labour, the excreta were pooled in 3 -day periods. It is obvious from the figures which follow when this was done.

Chemical estimations. Nitrogen was determined by the Kjeldahl method, using copper sulphate and selenium dioxide as catalysts during the incineration. Distillation was carried out in a Markham apparatus. From time to time the method was checked by analysis of urea solutions of known concentration. Phosphorus was estimated in stools after digestion with sulphuric and nitric acids, by the colorimetric method of Allen (1940).

\section{Comment on methods}

Observations confirming positive nitrogen balance. It is easy for the results of work of this kind to be vitiated by technical errors such as incomplete collection of excreta, or errors in recording the food intake. It was, in fact, the fear that one or both of these factors might be operating that made us stop the first series of observations which were carried out in the general wards of the hospital. It is only fair to the nursing staff of these wards to point out that the results we then obtained differed in no way from those subsequently obtained in the metabolic ward. We have already described the general precautions taken to eliminate these sources of error. We list below a number 
of observations which support the validity of the long-continued positive nitrogenbalances observed in our patients:

(I) Inspection of the graphs of nitrogen intake and retention, shown below, reveal that the changes in the nitrogen balance follow those of the nitrogen intake with considerable exactitude. If the positive balance were due to errors in collection of excreta or measurement of food intake, it could have occurred only if a constant percentage of either food or excreta had been lost. This could hardly have happened. Losses would have either been random, or constant in amount (e.g. if patients had succeeded in surreptitiously disposing of food) and in neither case would the variation of balance have then followed the supposed food intake.

(2) Patients could be (and on several occasions were) brought into nitrogen equilibrium or negative nitrogen balance by deliberately lowering the protein intake.

Table 2. Percentage of urinary nitrogen excreted as urea nitrogen by two African subjects on a constant high-protein diet

\begin{tabular}{|c|c|c|}
\hline Date & Gabriel & Malé \\
\hline $26-27$ ii. 52 & $83 \cdot 2$ & $72 \cdot 9$ \\
\hline $27-28$. ii. 52 & $67 \cdot 8$ & $70 \cdot 2$ \\
\hline $28-29$. ii. 52 & $78 \cdot 5$ & $8 \pi \cdot 5$ \\
\hline 29. ii. $52-$ I. iii. 52 & $79 \cdot 2$ & $77 \cdot 6$ \\
\hline 1-2. iii. 52 & $77^{\circ} 0$ & $85 \cdot 3$ \\
\hline $2-3$. iii. 52 & $78 \cdot 8$ & $8 \mathrm{I} \cdot 8$ \\
\hline $3-4$. iii. 52 & $77^{6} 6$ & $78 \cdot 1$ \\
\hline $4-5$. iii. 52 & $83 \cdot 1$ & $78 \cdot 5$ \\
\hline $5^{-6 .}$ iii. 52 & $73 \cdot 4$ & $85^{\circ} 0$ \\
\hline $6-7$. iii. 52 & $87 \cdot 3$ & $82 \cdot 4$ \\
\hline $7-8$. iii. 52 & $78 \cdot 7$ & 80.8 \\
\hline $8-9$. iii. 52 & $87 \cdot 4$ & $86 \cdot 5$ \\
\hline 9 -IO. iii. 52 & 83.7 & $86 \cdot 6$ \\
\hline $10-1$ I. iii. 52 & $76 \cdot 7$ & $84 \cdot 5$ \\
\hline I I-I2. iii. 52 & - & 84.0 \\
\hline Mean & $79 \cdot 4$ & $81 \cdot 0$ \\
\hline
\end{tabular}

(3) On a protein-rich diet, it is commonly found that urea nitrogen forms about $90 \%$ of the total urinary nitrogen. On a diet poor in protein the proportion of nitrogen excreted as urea is lower; and it would be expected also to be lower if a considerable proportion of the protein administered was being stored. This last point was investigated in two patients who had apparently been retaining nitrogen for a long time. The results are shown in Table 2, which indicate a mean figure of about $80 \%$ in each instance. This result is consistent with the finding of a markedly positive nitrogen balance during this time.

(4) On a high-protein diet it would be expected that the blood urea would lie near the upper range of normal values, unless a considerable amount of the protein was being stored. While taking a high-protein diet, one patient (Malé) on three occasions had blood-urea levels of 19,13 and $28 \mathrm{mg} / 100 \mathrm{ml}$; ; another (Gabriel) just before discharge had a level of $17 \mathrm{mg} / 100 \mathrm{ml}$, and blood-urea levels of about $20 \mathrm{mg} / 100 \mathrm{ml}$. were found in a number of other cases not reported in detail in this paper. A European control (M.W.S.) on a high-protein diet had a blood-urea level of $37 \mathrm{mg} / \mathrm{r} 00 \mathrm{ml}$. These findings, again, are consistent with the possibility of protein storage in the patients. 
Correction for cutaneous loss of nitrogen. Apart from nitrogen lost in urine and faeces, some loss of nitrogen must occur through the sweat and possibly other cutaneous secretions, and by the shedding of epithelial structures. These losses are commonly ignored in nitrogen-balance experiments, and are no doubt too small to introduce any serious error in experiments of short duration. They may, however, have greater effect when losses or gains of nitrogen over long periods are considered. Direct measurement of these losses over long periods is impracticable: at any rate, no satisfactory technique for measuring them seems so far to have been devised. Mitchell (1949) has approached the problem indirectly. He determined the nitrogen balance of twenty-three American students for periods of from 156 to 212 days. These subjects showed an apparent mean daily nitrogen 'retention' of $\mathrm{I} \cdot 379 \mathrm{~g}$. They showed a small mean loss of weight over the period. This he attributed in part to 'adult growth' (such as epithelial structures) and in part to loss by sweat. He suggested that in conditions of minimal sweating, $0.36 \mathrm{~g}$ nitrogen may be lost daily in sweat, equivalent to $0.772 \mathrm{~g}$ urea. Assuming that the concentration of urea in sweat is the same

Table 3. Difference between weights of nutrients entering and products leaving the bodies of African subjects as an index of the amount of water lost through sweating

\begin{tabular}{|c|c|c|c|c|c|c|c|}
\hline \multirow[b]{2}{*}{ Subject } & \multirow{2}{*}{$\begin{array}{l}\text { Period } \\
\text { (days) }\end{array}$} & \multirow{2}{*}{$\begin{array}{l}\text { Total food and } \\
\text { fluid intake } \\
\text { (kg) }\end{array}$} & \multirow{2}{*}{$\begin{array}{c}\text { Loss (urine, } \\
\text { faeces, respiratory } \\
\text { gases) } \\
(\mathrm{kg})\end{array}$} & \multirow{2}{*}{$\begin{array}{l}\text { Difference } \\
\quad(\mathrm{kg})\end{array}$} & \multirow{2}{*}{$\begin{array}{c}\text { Change in } \\
\text { body-weight } \\
(\mathrm{kg})\end{array}$} & \multicolumn{2}{|c|}{ Net loss (kg) } \\
\hline & & & & & & Total & Daily \\
\hline Azikali & ro & $4 I \cdot 4$ & $23 \cdot 20$ & 18.2 & $-1 \cdot 3$ & $19 * 5$ & $1 \cdot 9$ \\
\hline h & I5 & 56.0 & $21 \cdot 98$ & $34^{\circ} \circ$ & +0.2 & $33 \times 7$ & $2 \cdot 2$ \\
\hline Gabriel & 6 & $34 \cdot 0$ & II.90 & $22 \cdot 1$ & $-0 \cdot I$ & $22 \cdot 2$ & 3.7 \\
\hline Gabriel & 26 & $134^{\circ} 0$ & $54 \cdot 54$ & 79.9 & -0.5 & $80 \cdot 4$ & $3 \cdot 9$ \\
\hline
\end{tabular}

as that in the blood, and taking it as $25 \mathrm{mg} / 100 \mathrm{ml}$. this would be about 31 . of sweat lost daily. We have endeavoured to determine a maximum possible figure of loss by sweat by our subjects. If the total intake of food and fluid by mouth over a given period is measured, and compared with the weight of urine and faeces passed over the same period, and if the difference is corrected for any change in body-weight during the same period, the resulting figure will represent the loss of material from the body from all sources other than bowel and kidney. Besides cutaneous loss (sweat, other cutaneous secretions, shed epithelial structures) this figure will also include water lost by the lungs, and the net loss of weight involved in the exchange of respiratory gases. If, therefore, we take the whole of it to represent sweat, we cannot be underestimating the latter.

Table 3 shows the results obtained by observations of this kind on three of our subjects. They show that a figure of 41 ./day will be a very generous one to adopt for mean sweat loss. It would give us a figure of $1.0 \mathrm{~g}$ urea daily, or about $0.5 \mathrm{~g}$ nitrogen. Mitchell assigns approximately $\mathrm{I} g$ nitrogen to other cutaneous losses. Our subjects shaved very seldom, and their hair appeared to grow slowly. It seems therefore that allowance of a loss of $2 \mathrm{~g}$ nitrogen daily by routes other than urine and faeces will certainly err on the generous side, provided the assumptions made above are correct. It must be admitted that comparatively little is known about the physiology of the 
skin, but if large amounts of nitrogenous material can be lost by cutaneous structures, not only the present data, but a great number of others, will be invalidated.

\section{RESULTS}

\section{Control experiments}

Fig. I shows the results of observations on the nitrogen balance and intake of five normal subjects.

It will be noted that M.W.S., J.G. and B. were in nitrogen equilibrium on a diet containing $5^{-\mathrm{r}} 5 \mathrm{~g}$ nitrogen daily, a quantity which approximated to their habitual intake. When the intake was raised to $20-25 \mathrm{~g}$, as was done with M.W.S. and J.G., the immediate result was a marked retention of nitrogen, which tended to decrease, though in neither case had it reached zero by the time the high protein intake was discontinued. Both these subjects developed a dislike, amounting to loathing, for this high-protein diet, and it is doubtful whether they could have continued to consume it for a longer period.

Table 4. Tissue gain calculated from nitrogen retention (see p. 180), and observed change in weight, of four control subjects on a nitrogen-balance test

$\begin{array}{lcc}\text { Subject } & \begin{array}{c}\text { Calculated } \\ \text { tissue gain } \\ (\mathrm{kg})\end{array} & \begin{array}{c}\text { Observed change } \\ \text { in weight } \\ (\mathrm{kg})\end{array} \\ \text { R.M. (period I) } & +\mathrm{I} \cdot 38 & +0.10 \\ \text { R.M. (period 2) } & +\mathrm{I} \cdot 27 & +\mathrm{I} \cdot 90 \\ \text { M.W.S. (period 2) } & +0.94 & +\mathrm{I} \cdot 00 \\ \text { J.G. } & +0.36 & -\mathrm{I} \cdot 00 \\ \text { N. } & +0.67 & -0.70\end{array}$

N., an African student, was started on a high-protein diet. He showed a marked nitrogen retention, which, however, decreased as the experiment progressed. The nitrogen intake was deliberately lowered on the 8th day. He thereupon went into negative balance for $24 \mathrm{~h}$, but from the 9 th to the $14^{\text {th }}$ day was in equilibrium on an intake of about $\mathrm{I} 4 \mathrm{~g}$ nitrogen daily. He expressed no distaste for the high-protein diet. In contrast to these results many of our subjects in the ward have consumed $20 \mathrm{~g}$ or more nitrogen daily for many months without showing any signs of coming into nitrogenous equilibrium.

R.M. began, for the first few days, to consume a diet containing $250 \mathrm{~g}$ protein ( $4 \circ \mathrm{g} \mathrm{N}$ ) daily. This he found intolerable. He lowered it to $\mathrm{I} 80 \mathrm{~g}(28.8 \mathrm{~g} \mathrm{~N})$, at which level he was quite comfortable. It will be seen that he settled down to a steady nitrogen retention of about $6 \mathrm{~g}$ daily, which showed no sign of diminution throughout the period of observation. The calculated protein and tissue retention is shown in Table 4 . In this case the observed gain in weight over the whole period is less than the calculated tissue retention. The gain in weight, however, began only on the gth day of the high-protein diet. For the preceding days (period 1 ), although the calculated tissue retention was $\mathrm{I} \cdot 383 \mathrm{~kg}$, the weight remained virtually unchanged. For the remaining 12 days of observation (period 2), the calculated tissue retention was $1.269 \mathrm{~kg}$, while the gain in weight was $2 \cdot 0 \mathrm{~kg}$. 

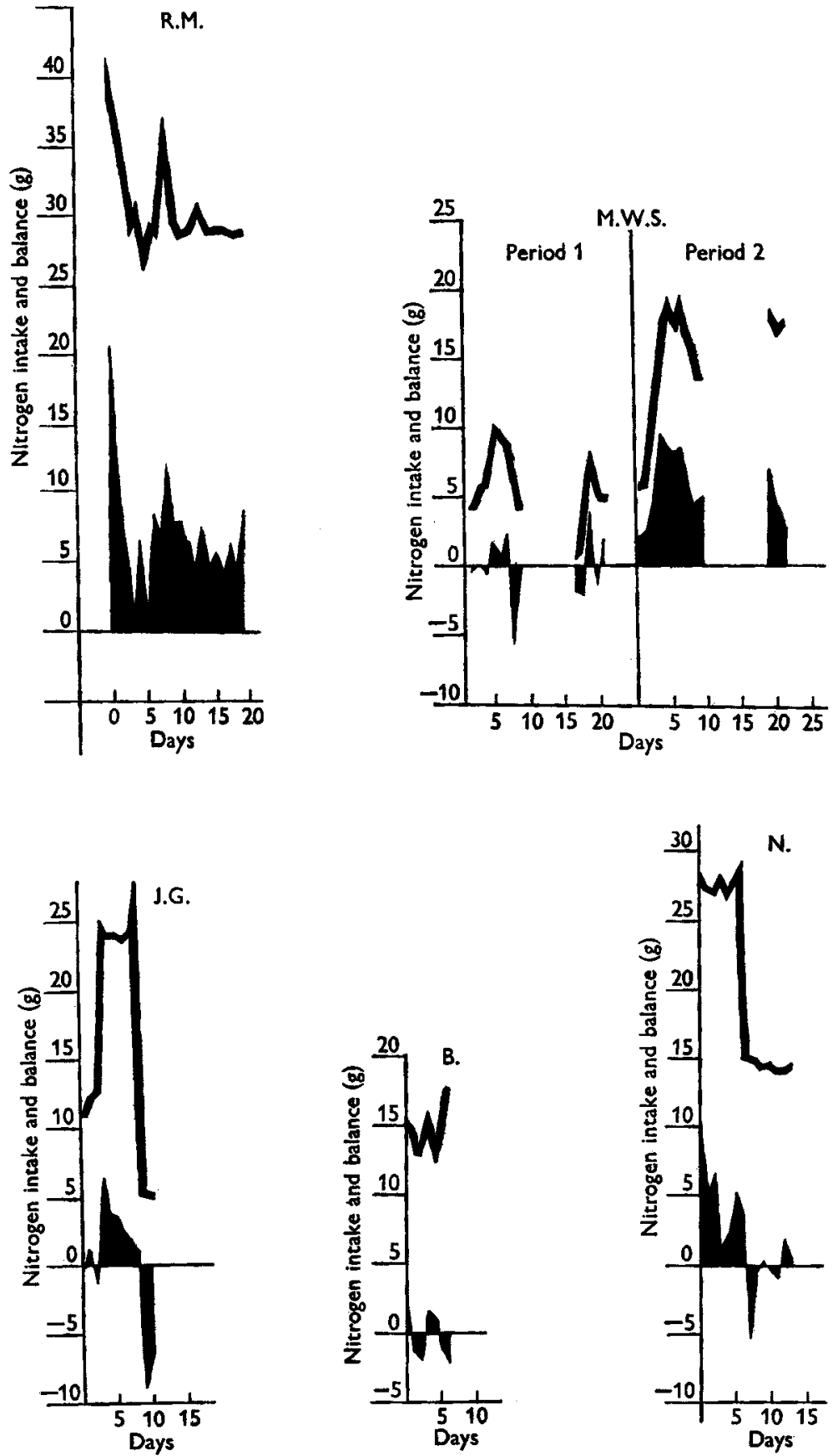

Fig. 1. Nitrogen intake and balance in control subjects (R.M., M.W.S., J.G., B. and N.). Upper lines, nitrogen intake (g); lower black areas, nitrogen balance $(\mathrm{g})$. 
In view of what follows, it is worth comparing the actual weight changes of these control subjects with the gain in tissue that might be expected from the observed nitrogen retention. The calculated tissue gain was arrived at by multiplying nitrogen retained in $g$ by 6.25 and multiplying the result by 3 , since water will presumably have to be retained with the protein, and the water content of tissues is said to be about $67 \%$. It will be noted that the 'calculated tissue gain' bears no relation to the change in weight observed.

We may conclude from these control observations:

(1) That the techniques used were adequate, except of course, that they made no allowance for cutaneous loss of nitrogen.

(2) That, at any rate over short periods, nitrogen retention need not necessarily be accompanied by a gain in weight. Presumably any increase in tissue mass may be masked by increase in fat oxidation, or changes in body water.

(3) A limit may be set to nitrogen retention by the inability of the subject to continue a very high rate of protein consumption. This phenomenon was noted particularly in our European controls: it was not observed in the African subjects.

\section{General}

\section{Clinical observations}

We have accumulated a mass of data about the clinical condition, haematology, and serum proteins of the subjects studied but, for the sake of brevity, only a few of these points will be touched on here. In all cases, the serum proteins measured both by electrophoresis and by chemical methods, gave low values for albumin, and an albumin:globulin ratio of less than unity. Those who were severely ill when first observed had greatly reduced values for both albumin and globulin, and both fractions at first rose on the high-protein diet. These observations are the subject of a separate communication (Stanier \& Holmes, 1954). All subjects were anaemic when first observed, and in all cases the red-cell counts rose during treatment, usually reaching 6 million red cells $/ \mathrm{mm}^{3}$, which is the mean R.B.C. count of healthy Africans at this altitude (Holmes, Gee, Asia, Bhima, Chagula, Evelia, Kasirye, Kiboneka, Lugazia, Majale, Mughairy, Ochieng, Gesa \& Magambo, I950).

Several of the patients were jaundiced when first observed, and in some cases liver damage was proved by biopsy. No patient failed to retain nitrogen when placed on a high-protein diet, whatever the initial diagnosis. The data for the nitrogen balances are presented in the form of graphs for individual subjects (Figs. 2 and 3 ) and a very brief clinical history is given below. In the three cases where phosphorus balances as well as nitrogen balances were carried out, the figures for phosphorus are also given.

The patients with severe hookworm infection were wormed at an early stage of treatment, and were given iron. Malarial infection, when it occurred, was treated with mepacrin, and other minor infections received appropriate treatment. The patients showed great clinical improvement. Clinically detectable oedema, if present, disappeared. The skin, usually initially dry and harsh, took on a silky, glistening appearance, and the hair, at first usually soft and partly depigmented, became black and crisp. In general, the subjects became strikingly 'younger' in appearance. Their physical strength and mental activity improved. Unfortunately, though naturally, 
Vol. 8

क्ष
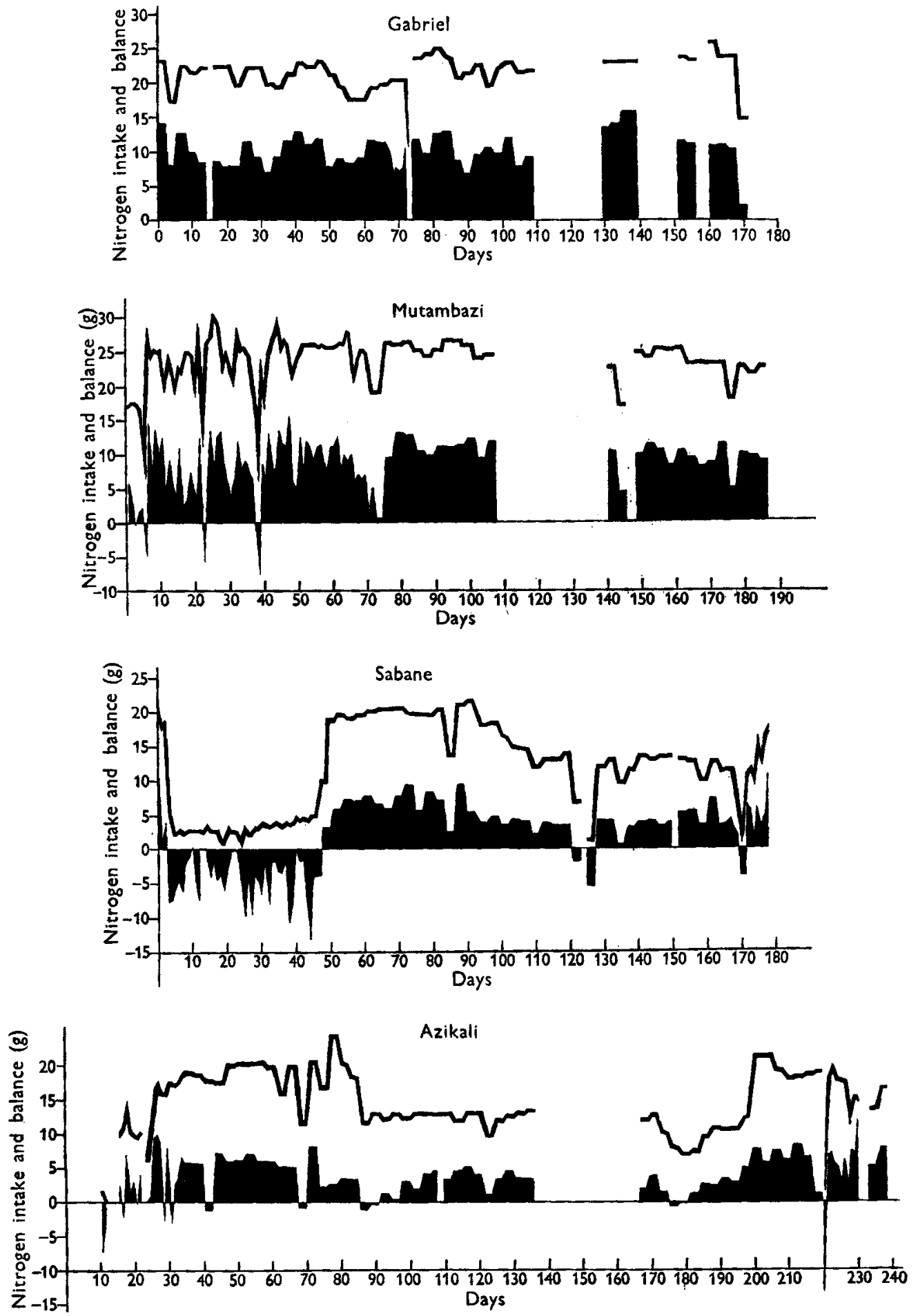

Fig. 2. Nitrogen intake and balance in four African patients (Gabriel, Mutambazi, Sabane and Azikali). Upper lines, nitrogen intake (g); lower black areas, nitrogen balance (g). 
this improvement frequently resulted in a desire to leave hospital, the subject became unco-operative and, if not discharged, absconded.

\section{Case histories of five subjects}

Mutambazi. Aged about 25. On admission: hookworm anaemia. No history of jaundice and none subsequently observed. R.B.C. ${ }^{\circ} \cdot 94$ million $/ \mathrm{mm}^{3}$. $\mathrm{Hb} 3 \cdot 6 \mathrm{~g} / \mathrm{roO} \mathrm{ml}$. On first worming, 2895 hookworms counted. During a period of 50 days, phosphorus balance as well as nitrogen balance was observed. During this period, he retained
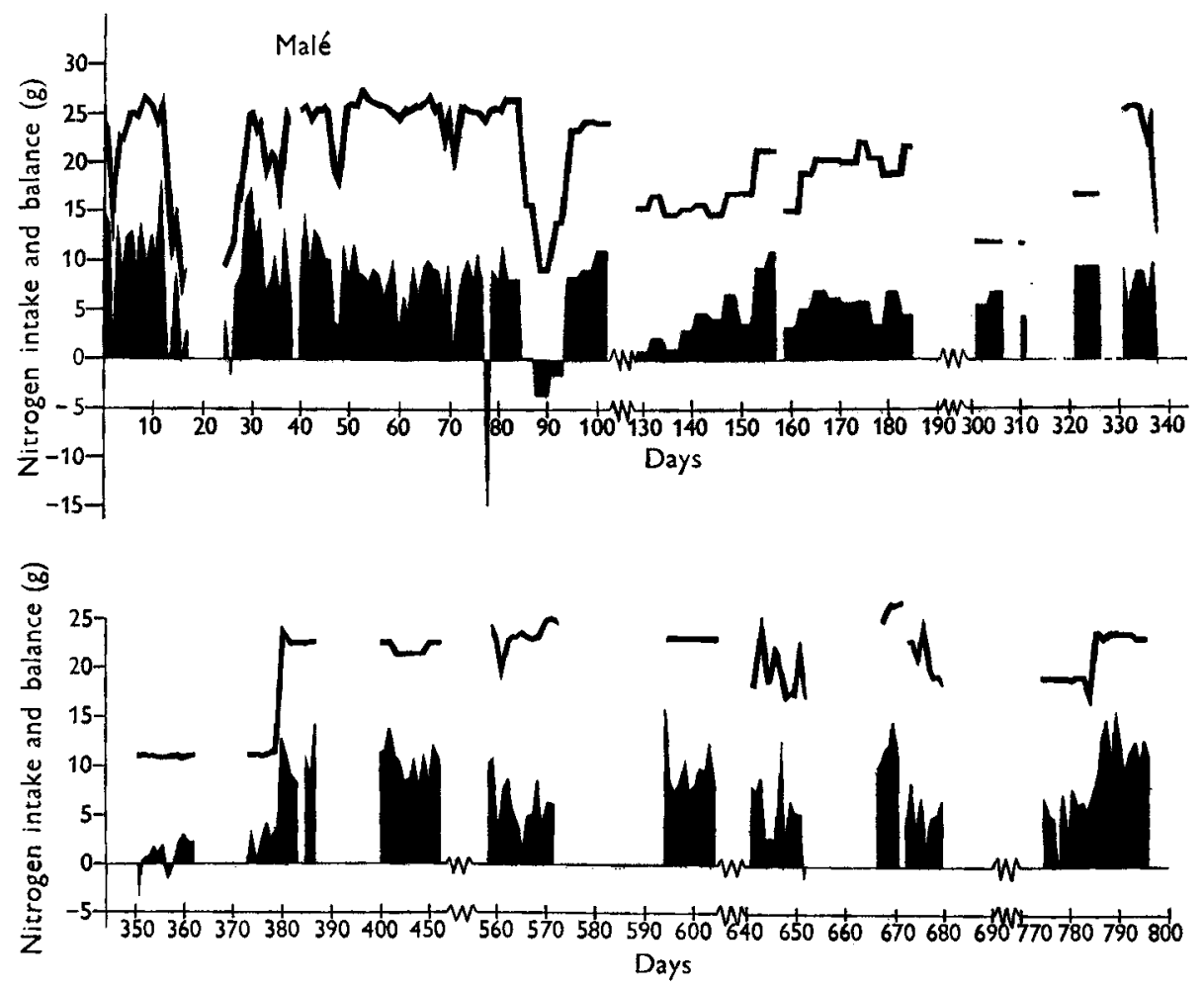

Fig. 3. Nitrogen intake and balance in Malé, an African patient. Upper line, nitrogen intake (g); lower black area, nitrogen balance $(\mathrm{g})$.

4I8.7 $\mathrm{g}$ nitrogen and $3 \mathrm{I} \cdot 3 \mathrm{~g}$ phosphorus. From day $\mathrm{I}$ to day IO8, the mean calorie intake was $3510 /$ day. From day 140 to day 185 the mean calorie intake was $3488 /$ day.

Sabane. Aged about 40. On admission: oedema of legs, feet and sacrum. Liver and spleen enlarged. R.B.C. 2.86 million $/ \mathrm{mm}^{3}$, rose to 6.06 million. $\mathrm{Hb} 5.2 \mathrm{~g} / 100 \mathrm{ml}$., rose to $15^{1} / 100 \mathrm{ml}$. On first worming 1225 hookworms counted. Phosphorus balance as well as nitrogen balance was carried out in this case during the first 29 days of observation, when, it will be seen from Fig. 2 , he was in negative nitrogen balance. During this period, $77^{\circ} \mathrm{g}$ nitrogen and $14.82 \mathrm{~g}$ phosphorus were lost. This patient refused to take milk in any form. He was wormed, and then allowed to continue on the vegetable diet (sweet potatoes, plantains, and maize meal) which he preferred, in order to test his haematological response to additional iron without additional protein. 
The results were interesting, but will not be discussed here. After this, meat was added to the diet. The mean calorie intake for days $\mathrm{I}-45$ (low protein intake) was $2227 \mathrm{Cal}$., for days $46-99,4132$ Cal., for days 100-16r, 2975 Cal., and for days $162-176$, $2187 \mathrm{Cal}$.

Azikali. Aged about 30. On admission: hookworm anaemia. R.B.c. $2 \cdot 86 \mathrm{mil}-$ lion $/ \mathrm{mm}^{3}$, rose to 6.05 million. Hb $5.2 \mathrm{~g} / 100 \mathrm{ml}$, rose to $16.4 \mathrm{~g} / 100 \mathrm{ml}$. On first worming 1225 hookworms counted. Mean calorie intake 3625 Cal.

Gabriel. Aged about 20. This subject was first seen at Mulago in 1949, when a liver biopsy showed a moderate amount of liver damage. He was admitted a second time in 1949 , and again in 1950 , for observation. On the second occasion his R.B.c. was $3.92 \mathrm{million} / \mathrm{mm}^{3}, \mathrm{Hb} \mathrm{I}^{\circ} .6 \mathrm{~g} / \mathrm{I} 00 \mathrm{ml}$. There was no history of jaundice. On fourth admission his R.B.C. was 3.76 million $/ \mathrm{mm}^{3}$. His liver was just palpable. There was no clinical oedema, and no evidence of hookworm infestation. As in Malé, his red-cell count rose only very slowly, and was unresponsive to iron and liver. It eventually reached 6.0 million. The mean calorie intake was $3577 \mathrm{Cal}$.

Malé (see Fig. 3). Aged about 50. On admission: emaciated, soft straight hair, glazed flaking skin. Slight jaundice. Liver and spleen enlarged. No oedema. R.B.c. $2 \cdot 21$ millions $/ \mathrm{mm}^{3}$ showing 'sickling', $\mathrm{Hb} 7 \cdot 8 \mathrm{~g} / \mathrm{ro0} \mathrm{ml}$. Liver biopsy indicated severe liver damage. Stools showed a few hookworm eggs only. On worming only thirtythree worms counted. His urine showed a trace of albumin, and was pink in colour. This was shown to be due to the presence of considerable amounts of urobilin.

After admission, he developed two severe attacks of jaundice, his R.B.c. rose to 4 million $/ \mathrm{mm}^{3}$ after II 5 days, and fluctuated between 3.5 and 4.0 million until the 57 oth day. Thereafter, it began to rise, and reached 6.5 million on the 638 th day. It then fluctuated between 5 and 6 million, until the 920th day, when it fell to 4.5 million. Since then, it has varied between 4.5 and 5.0 million. In the early stages of observation, treatment with iron, vitamin $\mathrm{B}_{\mathbf{1 2}}$, and liver extract, had no effect on the blood count. The increase in red-cell count and haemoglobin appeared much later, when he had no treatment other than the high-protein diet for many months. Observations on phosphorus balance, carried out for a period of 42 days, gave a figure of $30.5 \mathrm{~g}$ phosphorus retained. The corresponding retention of nitrogen was $336.3 \mathrm{~g}$. $\mathrm{He}$ is still under observation. There has been a great change in his condition since admission. His skin has become glistening and pliable, and his hair crisp. His mental condition has greatly improved, and his apathy and depression have been replaced by contentment. His liver and spleen remain hard and enlarged. For many months he had excreted considerable amounts of urobilin in his urine, but this became much less about the 6ooth day, when his blood count also began to climb towards 6.0 million. The mean values of the calorie intake during the various periods shown in Fig. 3 were as follows:

$\begin{array}{cccc}\text { Period (days) } & \text { Mean Cal./day } & \text { Period (days) } & \text { Mean Cal./day } \\ 0-19 & 266 \mathrm{I} & 521-560 & \text { 3142 } \\ 25-105 & 3276 & 625-638 & 2601 \\ 130-187 & 3298 & 705-716 & 2111 \\ 302-313 & 2905 & 736-749 & 2820 \\ 481-488 & 2792 & 838-860 & 3196 \\ 501-512 & 2421 & 956-964 & 3350\end{array}$




\section{Other observations}

In addition to these subjects, we have carried out nitrogen balances on six other subjects in the metabolic ward, for periods of $19,21,36,38,45$ and $I 14$ days respectively, and we had previously observed six other subjects, four females and two males, in the general wards. The shortest period of observation of these cases was 27 days, the longest 422 days. All retained nitrogen when on a high-protein, high-calorie diet, though they could be brought into nitrogenous equilibrium, or into negative balance, by lowering the protein intake. The amounts of nitrogen retained by these subjects were of the same order as those retained by the subjects discussed in detail.

\section{Protein-sparing action of high-calorie diets}

It has already been said that our subjects were maintained on diets high in calories as well as in protein. This was done primarily for therapeutic reasons. The calorie values of the diets are indicated in the protocols on each subject. It is well known that a high-calorie diet exerts a protein-sparing action. The very considerable literature on

Table 5. Effect of alterations in the total calorie intake on nitrogen retention of two African subjects

\begin{tabular}{|c|c|c|c|c|c|c|c|}
\hline Subject & $\begin{array}{c}\text { Period } \\
\text { (days) }\end{array}$ & $\begin{array}{l}\text { Calorie } \\
\text { intake } \\
\text { (Cal./day) }\end{array}$ & $\begin{array}{c}\text { Change } \\
\text { in calorie } \\
\text { intake }(a) \\
(\text { Cal. } / \text { day) }\end{array}$ & $\begin{array}{l}\text { Nitrogen } \\
\text { intake } \\
\text { (g/day) }\end{array}$ & $\begin{array}{c}\text { Nitrogen } \\
\text { retention } \\
\text { (g/day) }\end{array}$ & $\begin{array}{l}\text { Change in } \\
\text { nitrogen } \\
\text { retention }(b) \\
\text { (g/day) }\end{array}$ & $\begin{array}{c}\text { Nitrogen } \\
\text { spared/Cal. } \\
(b \div a) \\
(\mathrm{mg})\end{array}$ \\
\hline \multirow[t]{3}{*}{ Malé } & 12 & 2421 & & $11 \cdot 18$ & 0.72 & & \\
\hline & $\begin{array}{l}7 \\
7\end{array}$ & $\begin{array}{l}33 \text { or } \\
2102\end{array}$ & 880 & $\begin{array}{l}11 \cdot 19 \\
20 \cdot 05\end{array}$ & $\begin{array}{l}2 \cdot 22 \\
0.46\end{array}$ & $+I \cdot 50$ & $I \times 70$ \\
\hline & 10 & $325^{\circ}$ & 1148 & $22 \cdot 81$ & $11 \cdot 01$ & $+1 \cdot 55$ & $I \cdot 36$ \\
\hline \multirow[t]{3}{*}{ Gabriel } & 12 & 2800 & & $11 \cdot 32$ & $2 \cdot 30$ & & \\
\hline & $\begin{array}{l}7 \\
7\end{array}$ & $\begin{array}{l}3838 \\
2073\end{array}$ & 1038 & $\begin{array}{l}\text { II. I } 4 \\
20 \cdot 05\end{array}$ & $\begin{array}{r}3.67 \\
10.03\end{array}$ & $+I .28$ & $I \cdot 23$ \\
\hline & 13 & 3437 & 1364 & $21 \cdot 68$ & $10 \cdot 37$ & +0.34 & 0.25 \\
\hline
\end{tabular}

this subject is reviewed by Munro (I95r). There is ample evidence that in all animals, including man, an increase in calorie intake favours nitrogen retention. In our experiments, therefore, the high protein intake coupled with a high-calorie diet would naturally be expected to result in nitrogen retention. Table 5 shows that in two of our patients in which this point was directly investigated the nitrogen retention could in fact be altered by alteration in the calorie intake.

We have been unable to find records of any experiment in which nitrogen retention as the result of a high-calorie, high-protein diet given to a normal human adult was followed for more than a few weeks. If prolonged, it should, logically have one of two consequences. Either the subject will put on weight until nitrogen retention is terminated by a refusal any longer to consume the diet, or else, when some (undefined) 'optimum' condition of protein saturation has been reached, the nitrogen excretion will rise, and nitrogenous equilibrium will be established at a relatively high level of protein intake. The older teaching certainly was that nitrogenous equilibrium could be established at widely varying levels of protein intake. The observations on our controls suggest that the Europeans at least soon revolted against the very high protein diet, 
The nitrogen excretion of controls, B., M.W.S., J.G. and N. showed a tendency to increase, suggesting that eventually nitrogen retention would have been established at a high level of protein intake. Control R.M. continued steadily to retain nitrogen; on the other hand, he increased in weight.

\section{Body-weights}

The calculated gains or losses of tissue, together with the observed changes in weight over periods where the nitrogen balance was continuously observed, are shown in Table 6.

The observed nitrogen retention (or with Sabane, for one period, nitrogen loss) was corrected for the assumed cutaneous loss of nitrogen. The figure adopted for this correction (see p. I77) of $2 \mathrm{~g}$ nitrogen daily can hardly be an underestimate, and is

Table 6. Tissue gain or loss calculated from nitrogen balance, and observed change in weight, of five African subjects

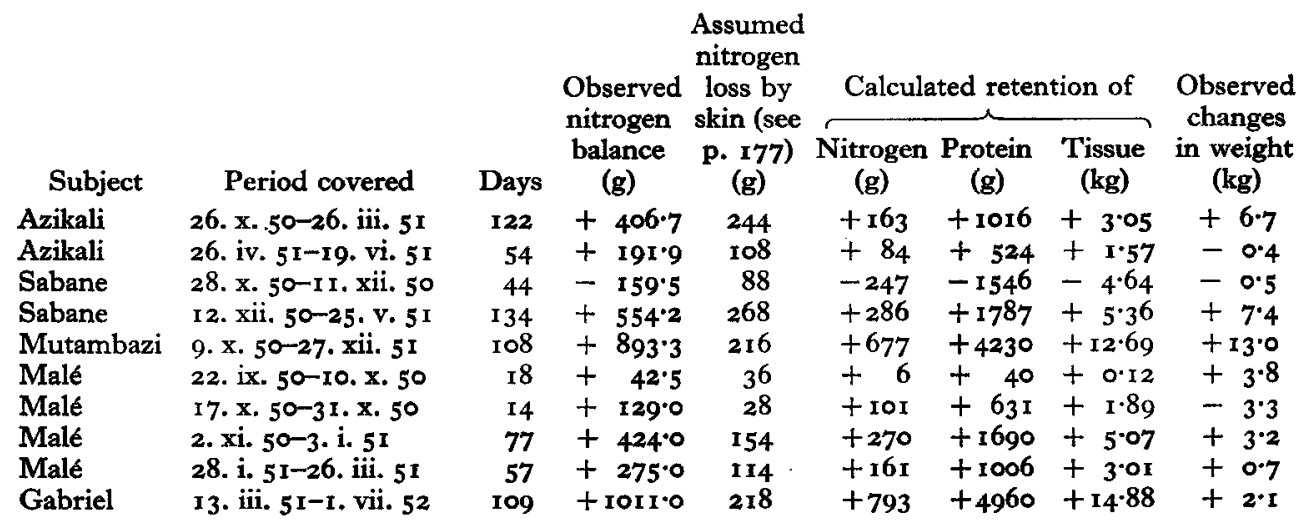

more likely to be too high. The resulting figure for net gain or loss of nitrogen was multiplied by 6.25 to convert it to protein and by 3 to convert it to tissue. The changes in body-weight to be expected from this calculation clearly bear no relationship to the changes actually observed. Only with Mutambazi do they nearly correspond, and this correspondence is probably accidental. It will be remembered that this lack of correspondence was found also in the figures for the controls.

\section{Partition of nitrogen between urine and faeces}

We have a large number of data on the faecal excretion of nitrogen by our subjects. Though the partition of nitrogen between urine and faeces is not relevant to our immediate problem, it is of some general interest, since it bears on the question of possible malabsorption of foodstuffs. In general, we have found the ratio of total nitrogen excreted to faecal nitrogen much lower in our patients than in our controls, i.e. the latter excreted a much lower proportion of their total nitrogen by way of the bowel. The results are shown in Table 7. They suggest that these subjects may absorb nitrogen with greater difficulty than the controls. The ratio of total nitrogen excreted to faecal nitrogen in the controls is of the same order as that usually quoted in the 
literature. Protein deficiency is associated both in children and adults (Thompson \& Trowell, 1952) with deficiency of digestive secretions, and it may be that in these cases there is malabsorption not only of proteins, but of other food constituents. Our observations show that the concentration of nitrogen per gram of dry stool was on the whole significantly greater in our African subjects than in our controls. It is of interest that though several of our subjects had, initially, very heavy hookworm loads, worming produced no significant change in the faecal nitrogen. That is to say, we have no evidence that in these cases hookworm infestation was a source of protein loss through the bowel.

Table 7. Ratio of total nitrogen excretion to faecal nitrogen in African subjects and controls

\begin{tabular}{lccc} 
African subjects : & \multicolumn{3}{c}{ Control subjects: } \\
Gabriel & $3 \cdot 45$. & B. (M.) & $8 \cdot 00$ \\
Sabane & $3 \cdot 29$ & M.W.S. (F.) & $6 \cdot 88 *$ \\
Male & $3 \cdot 37$ & N. (M.) & $12 \cdot 10$ \\
Mutambazi & $4 \cdot 37$ & J.G. (F.) & $12 \cdot 80$ \\
Azikali & $2 \cdot 78$ & R.M. (M.) & $15 \cdot 70$ \\
Matovu & $7 \cdot 23$ & & \\
Kabwa & $3 \cdot 42$ &
\end{tabular}

* In this instance the protein intake was considerably lower than in any of the others, either subjects or controls.

Table 8. Concentration of nitrogen in dried stools of African subjects and controls

\begin{tabular}{|c|c|c|c|c|c|}
\hline \multicolumn{3}{|c|}{ African subjects } & \multicolumn{3}{|c|}{ Control subjects } \\
\hline Name & $\begin{array}{c}\text { No. of } \\
\text { estimations }\end{array}$ & $\begin{array}{l}\text { Mean value with } \\
\text { standard deviation } \\
\text { (mg N/g dry } \\
\text { stool) }\end{array}$ & Initials and sex & $\begin{array}{l}\text { No. of } \\
\text { estimations }\end{array}$ & $\begin{array}{c}\text { Mean value with } \\
\text { standard deviation } \\
\text { (mg N/g dry } \\
\text { stool) }\end{array}$ \\
\hline Gabriel & I9 & $62 \cdot 8 \pm 3 \cdot 8$ & B. (M.) & 6 & $47 \cdot 5 \pm 5 \cdot 9$ \\
\hline Sabane & 21 & $59 \cdot 5 \pm 7 \cdot 3$ & M.W.S. (F.) & 13 & $47 \cdot 5 \pm 5 \cdot 7$ \\
\hline Malé & 33 & $52 \cdot 2 \pm 4 \cdot 7$ & R.M. (M.) & 19 & $57 \cdot 6 \pm 2 \cdot 8$ \\
\hline Mutambazi & 27 & $59 \cdot 0 \pm 5.8$ & & & \\
\hline Azakali & 26 & $67 \cdot 1 \pm 7 \cdot 2$ & & & \\
\hline
\end{tabular}

Supplementary experiments on the effect of cortisone on nitrogen balance

In the course of our studies we thought it worth while to try the effect of cortisone on the nitrogen balance of our subjects. Should its administration reduce the retention of nitrogen, a field for further investigation into the cause of the phenomena would be opened. Since serious effects can follow cortisone administration, we found it necessary to make a number of other observations besides those on nitrogen metabolism. The list was lengthened as the experiments progressed and finally included, in addition to daily weighings, measurements of urinary excretion of uric acid and chlorides, serum chlorides, serum potassium and total differential white blood-cell counts. Daily clinical observations, including recordings of blood pressure, were also made. These were the more necessary because we found that very high doses of cortisone were necessary to produce a clear-cut effect on the nitrogen balance. The subjects were five Africans, Malé, Gabriel, Matovu, Kabwa and Naigesente. 
The results of these experiments are shown in Fig. 4. The dosage is indicated, and attention is drawn to the large amounts administered. It seems desirable that each case should receive brief discussion. Of the subjects, Malé and Gabriel have already figured in the earlier part of this paper. The nitrogen balances and fluid volumes of Matovu and Kabwa had been previously studied, though the results are not reported. Both were in positive nitrogen balance.
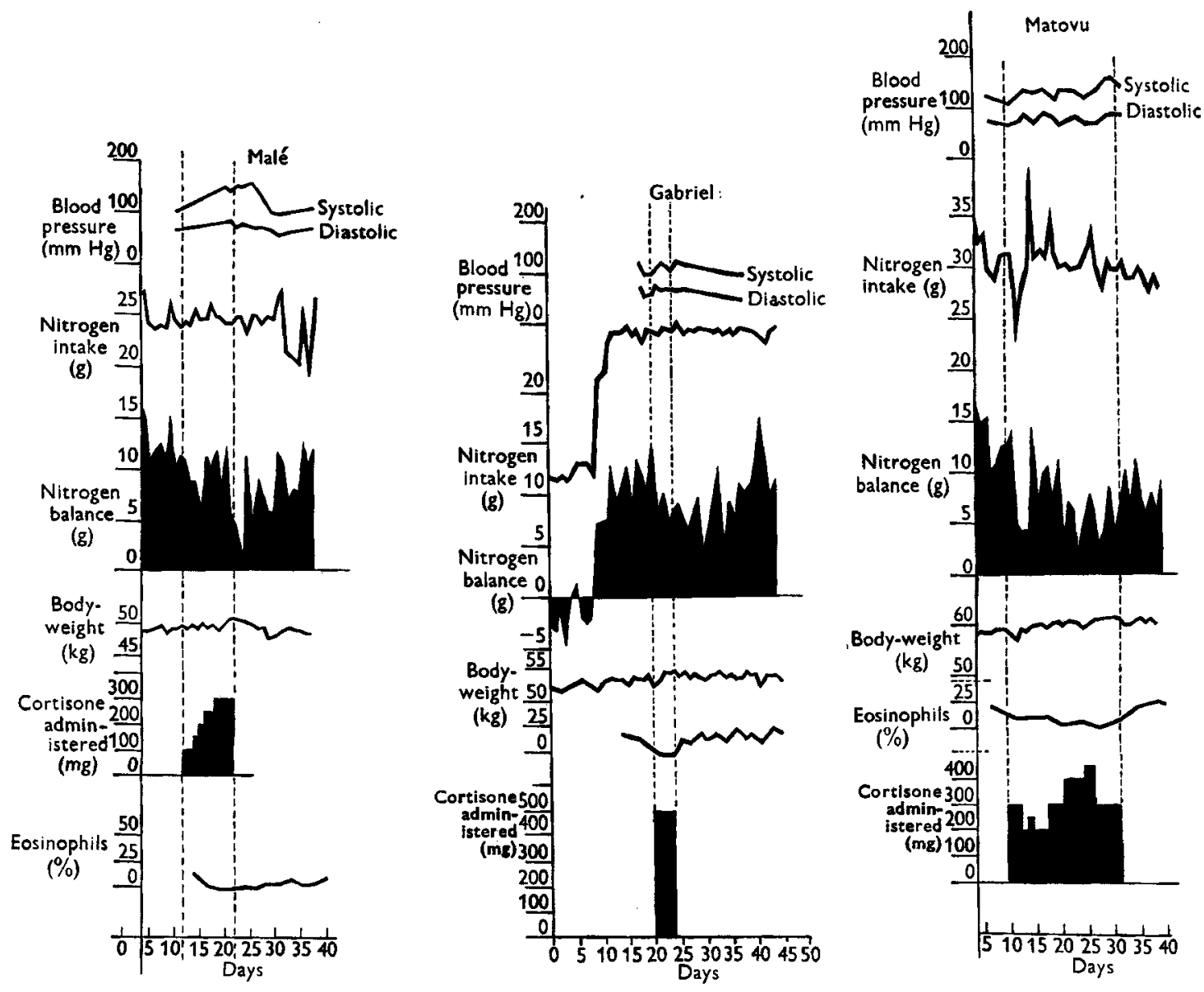

Fig. 4. Effect of cortisone on nitrogen balance, blood pressure, body-weight and eosinophils of three African patients (Malé, Gabriel and Matovu). Pair of dotted lines shows period of cortisone administration.

The total and extracellular fluid volume of Naigesente, but not his nitrogen balance, had been earlier investigated.

The first patient to receive cortisone was Kabwa. The substance was given by intramuscular injection. No result was obvious by the $\mathrm{i} 4_{\text {th }}$ day, when it was determined to abandon the experiment. On the succeeding days, however, there was an obvious decrease in nitrogen retention, coupled with a gain in weight, and a diminution of urine volume, which was eventually followed by a diuresis. Inspection of the retention 
curve makes it clear that the retention had, in fact, begun to decrease while cortisone was still being administered.

Malé also showed an obvious decrease in nitrogen retention. He is a frail, elderly man, and as he complained of headache, and his blood pressure was increasing it was thought wise not to prolong the administration of cortisone.

Matovu also showed a clear-cut effect. To him and subsequent patients the cortisone was given by mouth, as the amounts needed were inconveniently large for intramuscular injection. It is somewhat unfortunate that on one day he had an unexplained loss of appetite and that he was, regrettably, allowed an orgy of groundnuts next day, which caused a sharp rise in his nitrogen intake.

In Naigesente's case the dosage of cortisone was pushed up to $600 \mathrm{mg} / \mathrm{day}$ for 4 days. It was then lowered to $500 \mathrm{mg}$. On that day, he lost his appetite, and developed a bradycardia. The cortisone was then 'tapered off'. On the 14 th and $15^{\text {th }}$ days he was almost in nitrogen equilibrium on an intake of $25 \mathrm{~g}$ nitrogen daily. He then developed an acute bronchitis, with bradycardia, extra-systoles, and cardiac dilatation. He also had a carbuncle on his left hip, of which he denied knowledge until it was pointed out to him. This illness may have been purely fortuitous. It is, however, stated that cortisone increases susceptibility to infection, and also diminishes consciousness of pain. The effect of the cortisone on nitrogen retention is quite clear, in this case, even if the whole curve after the 8th day is ignored.

Gabriel was given to begin with a dose of $500 \mathrm{mg} /$ day of cortisone. The nitrogen balance at once became less positive. On the $4^{\text {th }}$ day, he complained of headache, and had some bradycardia. The cortisone was stopped, since the effect was already apparent, and the results might have been confused had he refused food.

It seems from these observations that the nitrogen balance of our subjects was affected by cortisone in the manner that might be expected from the findings of previous workers. So far as the other anticipated effects were concerned, we observed the following: (I) There was a rise in body-weight, followed, after stopping the cortisone, by a fall, accompanied by a diuresis. (2) The eosinophil count (initially high in all our subjects, as in most other Africans) decreased, usually to zero. (3) There was an increase in the output of uric acid in all three cases in which it was estimated. (4) There was a fall (though the lowest values were still just within normal limits) in serum potassium. (5) The changes in serum chlorides were somewhat inconsistent, as were those of urinary chlorides. A striking feature of these experiments was the very high dosage of cortisone necessary to produce an effect on nitrogen retention. The doses recommended for clinical administration do not exceed $300 \mathrm{mg}$, not commonly administered for more than $24 \mathrm{~h}$, after which the dosage is decreased. We have, in fact, failed to find an account of the effect of cortisone administered to a normal human being.

We think it extremely unlikely that the preparations we used were lacking in potency, for the following reasons:

(1) Three different preparations were employed. (a) A preparation by Schering Corporation for intramuscular administration. (b) A preparation by Merck and Co. Inc. (Rahway N.J.) for intramuscular administration, which was given both intramuscularly 
and by mouth. (c) A preparation by Boots Pure Drug Co. Ltd. (Nottingham) for oral administration.

(2) $300 \mathrm{mg}$ were administered for I day, followed by $200 \mathrm{mg}$ for the next 2 days to a normal European control (M.W.S.) and resulted in an alteration of nitrogen balance from slightly positive to slightly negative, a rise in uric-acid output, a rise in weight, followed by a fall in weight with diuresis.

Although we have not been able to find an account of the effect of cortisone on a normal subject, Conn, Louis, Wark \& Sprunger (1950) give an account of the effect of administrations of ACTH, that had a marked influence on nitrogen output, uricacid excretion, and eosinophil count in doses of 50 units daily. We have so far used ACTH (Corticotrophin powder, Organon Laboratories Ltd., London) on two subjects only, both of whom (Kabwa and Naigesente) had already been shown to respond to cortisone. Kabwa received 60 units for 5 days, followed by 40 units for I day; Naigesente was given 90 units for 2 days and 50 units for the 2 subsequent days. The results are shown in Fig. 5. Although ACTH lowered the eosinophil count in both cases it had no obvious effect in diminishing the nitrogen retention. We feel that these results open an interesting field for further investigation.

\section{DISCUSSION}

It is well known that starvation is accompanied by increase in extracellular fluid, which may give rise to gross clinical oedema, which disappears on rehabilitation. Gains or losses of tissue might, therefore, easily be masked by changes in extracellular fluid while these were taking place. As the period of observation lengthened, however, and nitrogen retention continued with a body-weight that remained about constant, it became more and more obvious that this explanation would no longer suffice.

Although in the early stages of observation the weight change may be either greater or less than the calculated tissue gain or loss, in the later stages it is obvious that in all cases the gain in body-weight is much less than would be expected from the calculated deposition of tissue. The only logical explanations of this observation are:

(I) That, owing to technical errors, the nitrogen retention was grossly exaggerated. We have examined this possibility at length, and have given our reasons for rejecting it.

(2) That the factor 6.25 , used for converting the figures for nitrogen to protein, is at fault. The figure is, of course, only an average one. Some proteins contain more than $16 \%$ nitrogen, some less, and the use of the figure 6.25 in our calculations may introduce some error. But it is very unlikely that such an error would be large.

(3) That the deposition of tissue protein is accompanied by the loss of other body constituents, in amounts corresponding, at least roughly, to the deposition of protein. These constituents might be water or fat. There is no doubt that extracellular water is lost in large amounts. Previous work by many observers has demonstrated this, e.g. Beattie, Herbert \& Bell (1948-9); Keys, Brožek, Henschel, Mickelsen \& Taylor (1950); Widdowson \& McCance (I95I). We (unpublished observations) have found that repeated determinations of extracellular fluid by the sodium-thiocyanate method show a progressive fall. But the expected tissue gain is, in many cases, too great to have been balanced by loss of extracellular fluid alone; and the retention of nitrogen 
without gain in weight continued, in some instances, after the figure for extracellular fluid had reached normal values. We are thus forced to consider whether or not there may also be a change in intracellular fluid. If, initially, the tissues contained more than $67 \%$ of water, which they slowly lost as protein was deposited, very considerable depositions of protein might be masked.
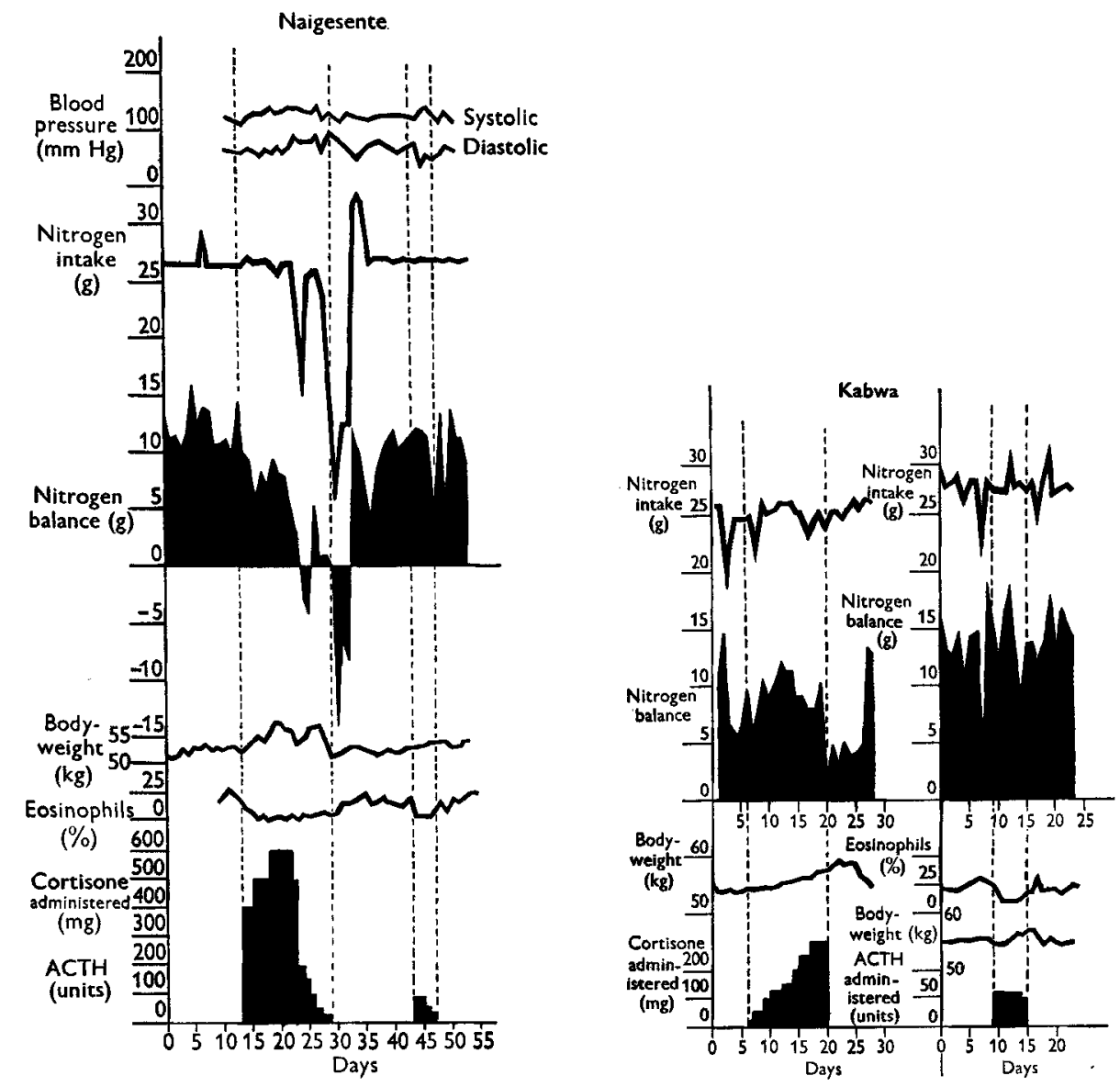

Fig. 5. Effect of cortisone and ACTH on blood pressure, nitrogen balance, body-weight and eosinophils of one African patient (Naigesente) and effect of cortisone and ACTH on nitrogen balance and bodyweight and of ACTH on eosinophils of another (Kabwa). Left-hand pairs of dotted lines show period of cortisone administration; right-hand pairs show period of ACTH administration.

We have approached this problem by determinations of both extracellular and intracellular fluid. The problem is a complicated one, especially as there appears to be no general agreement as to the validity of any of the methods at present available, and our observations are still continuing. We hope to make them the subject of a later communication, but in the meantime we would say that the results we have obtained do indicate that initially both extracellular and intracellular fluid are increased, and that they diminish as the high-protein, high-calorie diet is given. Finally, there is the question of loss of fat. In general, of course, starved people lose their body fat. It has therefore occasioned surprise that at post-mortems on individuals dying from 'malnu- 
trition' here, it is common to find considerable amounts of fat in the usual situations. It will be remembered that we are dealing with a protein deficiency, which, owing to the high carbohydrate content of the diet, is not accompanied by a corresponding calorie deficiency. In spite of the high calorie (as well as high protein) content of the diet we have given, our subjects remain lean. Observations on basal metabolic rate have yet to be made. If, however, it is initially low, as seems probable, and if it increases on protein feeding, and if considerable amounts of fat are thereby utilized, there may be considerable diminution of body fat. In 'starvation' a decrease in B.M.R. amounting to $430 \mathrm{Cal}$./day has been observed (Du Bois, I936). If, on protein feeding in our cases, there was an increase in B.M.R. amounting to $45^{\circ} \mathrm{Cal}$./day, this might entail the daily loss of $50 \mathrm{~g}$ of fat, the removal of which would mask the deposition of a corresponding amount of other tissue. If the fat content of the body were initially 'normal' it would amount to at least $5 \mathrm{~kg}$. The deposition of some protein might, therefore, be masked by the removal of fat. The failure to gain weight may thus be due to a progressive loss of fat, of extracellular, and intracellular fluid, as protein is deposited. This of course implies that the protein deficiency has produced a gross and fundamental alteration in the proportion of the body constituents.

Our observations are not without parallel, for Cook \& van Auken (195I) record similar results on a group of subjects with liver damage, one of whom had been a P.O.W. in Japanese hands and had been for a long time on a protein-deficient diet. These authors found very prolonged nitrogen retention, without any corresponding change in weight. They were unable to offer any explanation for this.

Karambelkar, Patwardhan \& Sreenivasan (1950) and Patwardhan, Mukundan, Rama Sastri \& Tulpule (r949) have observed a consistent retention of nitrogen in adult men on diets containing Io-r $5 \mathrm{~g}$ nitrogen. The retention was greatest when most of the protein was of vegetable origin, and diminished when a higher proportion was of animal origin, the total protein being kept constant. The experiments continued for considerably shorter periods than did our own. The observed body-weight changes did not tally with the expected deposition of protein.

A recent paper by Bray (I953) on nitrogen balances in West African children records results similar in several ways to our own. On a diet containing a moderate amount of animal protein, her subjects retained nitrogen for prolonged periods. The nitrogen retention, expressed as a percentage of the nitrogen intake, was much greater than the nitrogen retention, similarly expressed, of a group of American children studied by Macy (1942). The gain in weight of her subjects was much less than the expected tissue deposition; like ourselves, she considers the possibility of water loss as an explanation, but is not yet prepared to offer quantitative evidence on the point. She finds that the faecal nitrogen forms a higher proportion of the total nitrogen excretion than is usually found.

Our observations on the effect on nitrogen storage were begun because of reports in the literature that cortisone had a striking effect on the nitrogen metabolism of experimental animals, and of patients. For example, Clark (I953) has found that in rats the effect of cortisone is to diminish protein synthesis. Long, Katzin \& Fry (r940) showed that the administration to normal or adrenalectomized rats and mice of 
adrenal cortical extracts and of some of the sterols purified therefrom, caused, among other effects, an increase in nitrogen excretion, which the authors attributed to increased carbohydrate formation from protein, and which was accompanied by a rise in blood sugar and an increased deposition of liver glycogen. They found evidence suggesting that, in addition, the oxidation of glucose was diminished, since the nonprotein R.Q. fell. It seems likely, since the total oxygen consumption was not reduced, that there was increased oxidation of fat. In partially depancreatized animals, adrenal cortical extract greatly increased glucose excretion. In man, it is accepted that cortisone, especially in large dosage, will increase the nitrogen excretion, and give rise to glycosuria. Other effects are to increase the output of uric acid, to increase serum albumin and lower serum globulin, to give rise to retention of water and sodium chloride, and to lower the eosinophil count. Similar results are produced by ACTH which is believed to act by increasing the output of cortisone from the adrenals (Sayers, Sayers, Liang \& Long, 1946).

We are not yet in a position to provide a full explanation of the nitrogen metabolism of our subjects. However, our observations of the effect of cortisone on their nitrogen storage suggest that their nitrogen metabolism was under hormonal influence, and it is possible that endocrine imbalance may have occurred during malnutrition.

SUMMARY

I. The nitrogen balance of Africans who have lived for a long time on diets very deficient in protein has been observed for long periods.

2. On a diet high in protein and calories they retained nitrogen at rates of up to Io g/day continuously for months.

3. Although they thus appeared to be depositing tissue, their gain in weight did not nearly correspond to the calculated amount of tissue laid down. Possible explanations of this finding are considered.

4. The proportion of nitrogen lost in the faeces was considerably greater than that of control subjects.

5. Reasons are given for thinking that the observed nitrogen retention would not have been significantly lower if the cutaneous loss of nitrogen had been measured.

6. The retention of nitrogen was markedly diminished by cortisone, and was therefore under hormonal control.

Our thanks are due to the medical authorities of Mulago Hospital, Kampala, and to the technical and nursing staff of R/I44 Research Unit, Makerere College, Kampala, for their co-operation.

\section{REFERENCES}

Allen, R. J. L. (1940). Biochem. F. 34, 858 .

Beattie, J., Herbert, P. H. \& Bell, D. J. (1948-9). Brit. F. Nutr. 2, 47.

Bray, B. (1953). Brit. $\mathscr{~}$. Nutr. 7, 3.

Clark, I. (1953). F. biol. Chem. 200, 69.

Conn, J. W., Louis, L. H., Wark, S. \& Sprunger, B. (1950). F. clin. Endocrin. ro, 2.

Cook, W. R. \& van Auken, H. A. (1951). Ann. intern. Med. 34, 1404.

Du Bois, E. F. (1936). Basal Metabolism in Health and Disease. London: Baillière, Tindall and Cox.

East African Statistical Department (1952). The pattern of income and expenditure and consumption of labourers in Kampala, Sept. $195^{1 .}$. 
Fox, F. W. \& Goldberg, L. (I944). Publ. S. Afr. Inst. med. Res. 9, 123.

Holmes, E. G., Gee, F. L., Asia, S. B., Bhima, S., Chagula, W. K., Evelia, T. R., Kasirye, J. W. S., Kiboneka, G. H., Lugazia, M. Y., Majale, M., Mughairy, M., Ochieng, E. C., Gesa, J. I. \& Magambo, J. C. (1950). E. Afr. med. Ұ. 27, 360 .

Karambelkar, P. V., Patwardhan, V. N. \& Sreenivasan, A. (1950). Indian F. med. Res. 38, $24 \mathrm{I}$.

Keys, A., Brožek, I., Henschel, A., Mickelsen, O. \& Taylor, H. L. (1950). The Biology of Human Starvation, Vols. 1 and 2. Minneapolis: University of Minnesota Press.

Long, C. N. H., Katzin, B. \& Fry, E. G. (1940). Endocrinology, 26, $3 \circ 9$.

Macy, I. G. (1942). Nutrition and Chemical Growth in Childhood. Springfield, Ill.: C. C. Thomas.

Mitchell, H. H. (1949). Arch. Biochem. 21, 335.

Munro, H. N. (195I). Physiol. Rev. 3r, 449.

Patwardhan, V. N., Mukundan, R., Rama Sastri, B. V. \& Tulpule, P. G. (I949). Indian F. med. Res. $37,327$.

Platt, B. S. (1945). Spec. Rep. Ser. med. Res. Coun., Lond., no. 253.

Roberts, J. I. (1949). F. Trop. Med. (Hyg.); 52, 225.

Sayers, G., Sayers, M. A., Liang, T.-Y. \& Long, C. N. H. (I946). Endocrinology, 38, I.

Stanier, M. W. \& Holmes, E. G. (1954). Brit. F. Nutr. 8, I 55.

Thompson, M. D. \& Trowell H. C. (1952). Lancet, 262, 1031.

Widdowson, E. M. \& McCance, R. A. (195I). In Spec. Rep. Ser. med. Res. Coun., Lond., no. 275, p. I65. 